\title{
The effect of tax revenue, investment and foreign debt on poverty level
}

\author{
Andi Sessu \\ Faculty of economics and business \\ UHAMKA Jakarta, Indonesia
}

\begin{abstract}
Indonesia economic development, especially in the three macro-economic variables, namely tax revenues, foreign debt and developments of investment from 2002 to 2017 can be categorized as increasing and the number of poor people can also be categorized as decreasing. The results of multiple regression analysis show that tax receipts and investment developments have not been able to reduce poverty levels, because with high tax revenues originating from high individual and corporate taxes can affect the level of prices by itself demand decreases, as a result companies also reduce production and investment activities affect the decline in employment opportunities that can give birth to unemployment and poverty, one of which is also the reason for the receipt of taxes in part by corruption by certain people and the entry of high foreign workers. The foreign debt can reduce the poverty level, because the greater the foreign debt the more developing development activities that can absorb labor that affect the decline in unemployment and poverty rates. Multiple correlation coefficient ( $r$ ) of 0.947 means that there is a very strong relationship between all three variables studied, while the coefficient of determination $\left(R^{2}\right)=0.896$ or $89,6 \%$ of the number of poor can be affected by variables of tax revenue, loans overseas and investment development. The remaining $\mathbf{1 0 . 4 \%}$ is influenced by other factors. The results of this study explain the importance of government policies to always suppress foreign labor and imports as well as increase the quality of human resources both character quality and human resource competencies. Preservation of natural resources is very important to be done through sustainable efforts, both those carried out by the community, companies and the government so that the national economy will increase in the future.
\end{abstract}

Keywords: Investment, foreign debt, tax revenue, poverty level

\section{INTRODUCTION}

The national development, especially in the Indonesian economy since the old order up to the new order, has been quite encouraging, compared to several other countries in the world. However, the problem of unemployment, poverty and corruption is still very high compared to several other countries in the world. Data shows that Indonesia's poverty and unemployment rates from 2014 to 2018 are declining, so it is very important to do an in-depth analysis of national economic developments so that these problems can be minimized even if it is possible to immediately eliminate them. Data on unemployment and poverty in Indonesia in the last 4 years, from 2015 to 2018, the lower the poverty rate and unemployment rate can be shown in following the table: 
Table 1: Unemployment and Poverty level in Indonesia from 2015 - 2018

\begin{tabular}{ccc}
\hline \multirow{2}{*}{ Years } & \multicolumn{3}{c}{ Percentage (\%) } \\
\cline { 2 - 3 } 2015 & Unemployment & Poverty level \\
2016 & 6.18 & 11.13 \\
2017 & 5.61 & 10.64 \\
2018 & 5.50 & 10.12 \\
& 5.13 & 9.84 \\
\hline
\end{tabular}

Source: Ministry of Finance Indonesia (2018)

Based on macro and micro conditions of tax revenues, foreign debt and development of investment shows that the three variables have a very large influence towards increasing national income and can automatically increase investment and open opportunities for employment opportunities so that it can affect the decline in unemployment and poverty levels. This reality is the reason for researchers to examine the relationship between variables of tax revenue, foreign debt, development of investment with poverty levels in Indonesia.

Investment in Indonesia has the potential to increase its development,because Indonesia is very rich in natural resources and human resources, except that the quality of human resources needs to be improved in terms of both quality and quality of character and natural resources. For this purpose, awareness is needed to preserve and control, which can be done by society, companies and the government, so that the national economy is getting better which then impacts on the low levels of unemployment and poverty in Indonesia. Because at this time Indonesia is still one of the countries with relatively higher levels of poverty and unemployment compared to some other countries in the world.

\section{Foreign debt}

\section{LITERATURE REVIEW}

Foreign loans or foreign debt are a portion of a country's total debt obtained from creditors from outside the country, this form of debt can be in the form of money obtained from private banks, governments of other countries, or international financial institutions such as the IMF and the World Bank, or a number of funds borrowed and obtained from other countries (bilateral). The results of previous studies provide evidence that there is a significant influence between economic growth and foreign debt and foreign investment, the contribution of economic growth to foreign debt of 57.40\% (Purwanto \& Mangeswuri, 2011).

\section{Development of Investment}

Investment or commonly referred to as investor is a term with several definitions related to economics and finance. The term relates to the accumulation of a form of asset with an expectation to gain profit in the future. Investment expenditure or what is referred to as an aggregate economic variable is gross domestic domestic investment. This economic variable includes all domestic expenditures carried out by the private sector to establish new buildings, new machinery and equipment and changes in the number of various types of company inventory. The results show that gross domestic product and interest rates have a significant positive effect on direct investment in Indonesia while the exchange rate has a negative effect on direct investment in Indonesia (Malisa \& Fakhruddin, 2017).

\section{Tax revenue}

Receipt of tax is a contribution of the people paid to the state based on the law, so that it can be forced, by not receiving direct remuneration. In the other part of the tax or tax is the money or purchasing power that is surrendered by the public to the government where the money is 
given (purchasing power), the government does not provide direct remuneration. Submission of public money to the government can be done in the form of income tax, wealth tax, inheritance tax, sales tax, or all of which are referred to as taxes. The results of previous studies provide evidence that taxpayer compliance and disbursement of tax arrears have a significant effect on tax revenues. The results of the study provide recommendations that increasing taxpayer compliance can be done through counseling so as to create public awareness to pay taxes, as well as to disburse tax arrears so that tax revenues are more optimal and can be increased in the future (Molle et al., 2014).

\section{Poverty level}

The problem of poverty is a classic problem that has become a global issue. Poverty is a situation where there is an inability to fulfill basic needs such as food, clothing, shelter, education, and health. Poverty can be caused by scarcity of tools to fulfill basic needs, or the difficulty of access to education and employment. Some people understand this term subjectively and comparatively, while others see it from a moral and evaluative point of view, and others understand it from an established scientific perspective, and so on. The work achieved by The National Team for the Acceleration of Poverty Reduction (National Team for the Acceleration of Poverty Reduction or TNP2K) showed in 2011 that the higher the level of education at the head of the household will further reduce the likelihood of the household falling into poverty.

The President Susilo Bambang Yudoyono and Boediono era, the poverty rate in Indonesia was targeted to only reach $8 \%$ to $10 \%$. To achieve this target, the Government implemented a poverty reduction program grouped in 3 clusters. The first cluster is a family-based poverty reduction program, such as health assistance, education and also a family hope program (PKH); The second cluster is a community empowerment-based poverty reduction program such as the Indonesian National Community Empowerment Program or PNPM-Mandiri (National Program for Community Empowerment); and the third cluster, is a micro and small business based poverty reduction program. High economic growth correlates with the continuing decline in poverty (The National Team for the Acceleration of Poverty Reduction (National Team for the Acceleration of Poverty Reduction or TNP2K), 2011). Empirical facts show that the decline in the unemployment rate does not have a significant effect on poverty, because the number of poor people living in the regions is greater than those living in cities. Statistically, gross regional domestic product (gross regional domestic product or GDP) and other variables such as public expenditure have a significant effect on poverty while the unemployment variable does not significantly influence poverty (Rusdarti \& Sebayang, 2013).

\section{METHODS}

This research was carried out at the Central Agency on Statistics (Indonesia-Jakarta) and the offices of related agencies, namely the ministry of trade and industry. The sample used in the study is the overall national data related to tax revenues, foreign debt, increasing investment and poverty levels in Indonesia since the last 15 years, starting from 2002 to 2017. The design of the analysis used includes descriptive statistics to provide an overview general in research and inferential statistics to test hypotheses, which are then followed by multiple linear regression analysis.

\section{RESULTS}

Most of the studies have used income to identify poor households. We have two problems with this procedure. First, the official poverty line in Indonesia is consumption expenditure. Secondly, data is obtained from household expenditure surveys. We therefore compare a person 's consumption expenditure with the poverty line to determine its poverty status. This 
agrees with the idea that poverty is the inability to attain a critical minimum amount of consumption. The level of aggregation, from the individual, or household, microeconomic level to the macroeconomic, or countrywide, level. Mechanisms of underlying poverty traps at different levels of aggregation are similar, as suggested by Barrett \& Swallow (2006). We refer interested readers to recent surveys of this literature in Barrett \& Carter (2013), who consider mainly microeconomic aspects, and discuss the available evidence at the aggregate level. Hausmann et al. (2005) admitted that escapes from the poverty trap might, at the aggregate level, be responsible for some of the observed growth accelerations. However, the researchers did not follow this route, they were just the result of a change in the long run, with either reforms, external shocks, or political shocks.

Figure 1: Indonesian Poor householders since 2002 - 2017

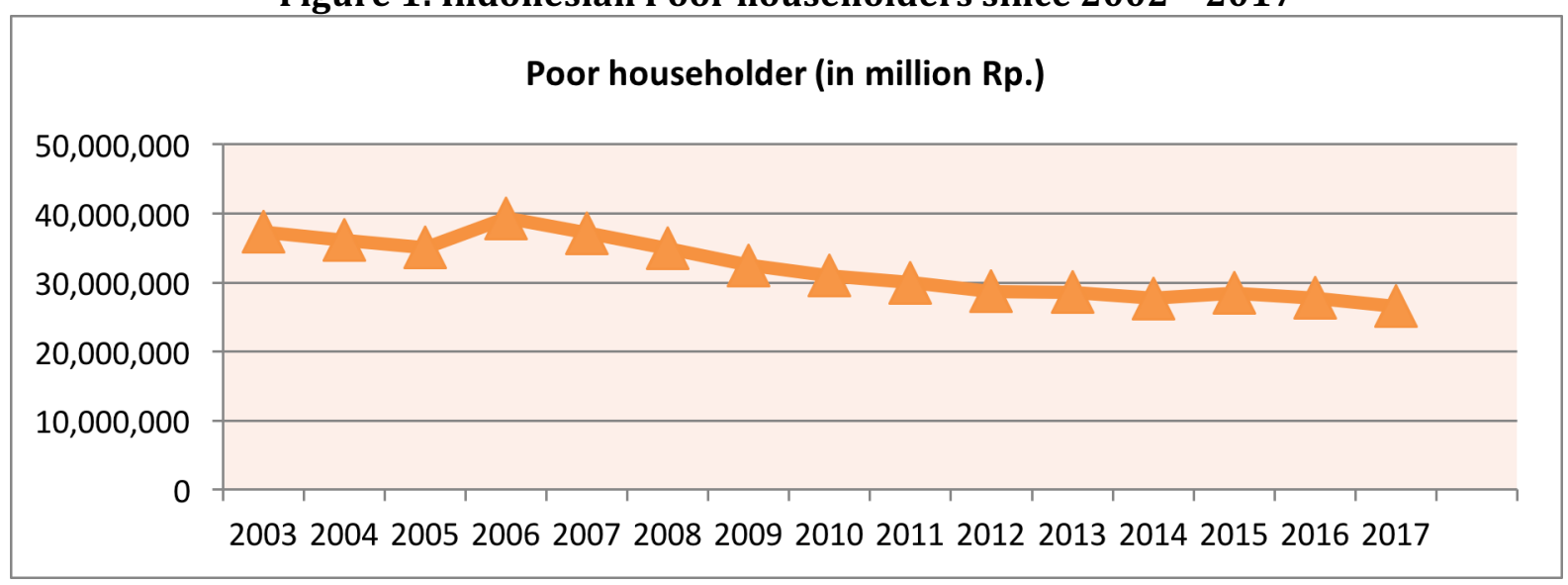

The number of poor people in Indonesia from 2002 - 2017 shows that with economic development can reduce the number of poverty from 2002 to 2005 decreased, only in 2006 increased and again declined again in the year 2007 to 2017. The policy can be considered as a country to sustain and strengthen its economic growth and global competitiveness. It provides countries with stable and predictable fiscal environment; thus, enabling them to accumulate funds to their finance social and physical infrastructure needs. Combined with economic growth, effective tax policies reduce long-term reliance on aid and ensure good governance by promoting the accountability of governments to their citizens. Although the exact impact of taxation on economic growth, the nature of the causal links between these two macroeconomic variables is equally crucial. If there is a causal flow from taxation to economic growth, this will suggest that the policymakers can count on fiscal policy tools to influence economic activities. Indeed, this is the policy implication of Keynesian theories. However, there is no causal flow between taxation and economic growth - which is implied policy implication of the long run then tax policy as a fiscal policy will be effective. 
Figure 2: Indonesian Tax revenue since 2002 - 2017

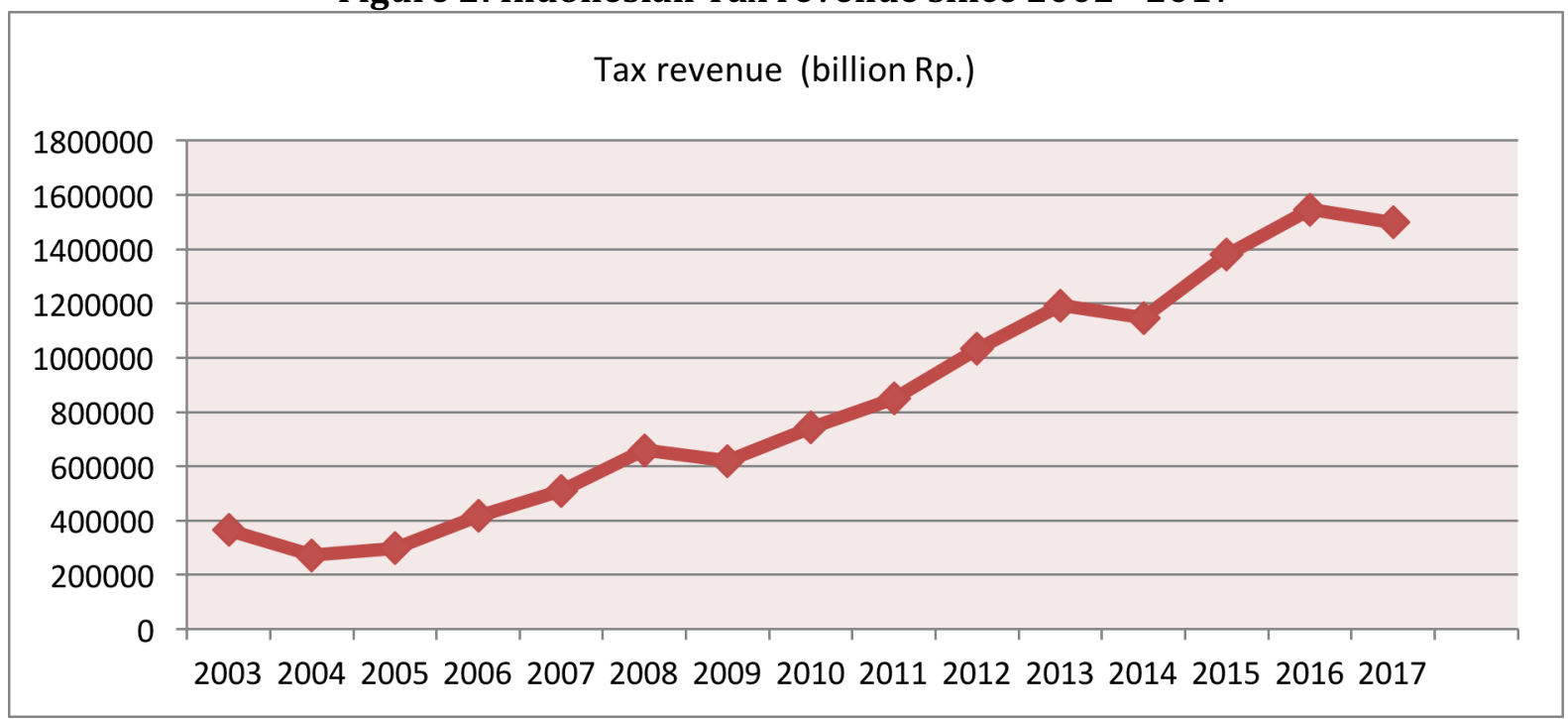

Indonesian tax revenues from 2002 - 2017 shows that tax revenues increased in 2003, in 2004 decreased, in 2005 to 2008 increased, in 2009 decreased, in 2010 increased until 2013, in 2014 it fell, increasing again until 2016 fell again in 2017. It can be concluded that tax revenues from 2002 to 2017 generally increased. A bad country economy has an impact on economic development that cannot run smoothly. Economic development is one of the efforts of the Indonesian government to improve the welfare of the community and improve the standard of living of the people so that they are far from the poverty line.

Figure 3: Indonesian Foreign debt since $2002-2017$

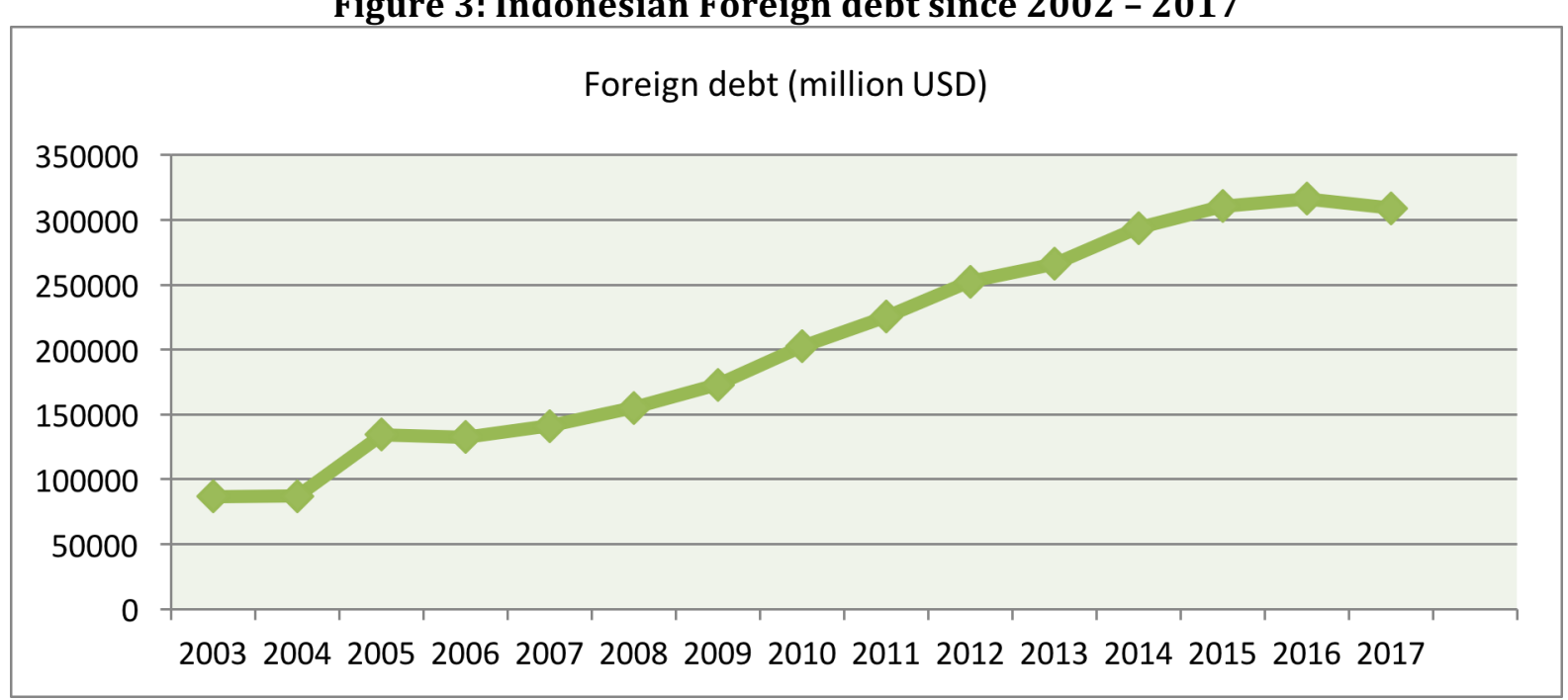

Indonesia's foreign debt from 2002 - 2017 shows that from 2002 it increased until 2005, declined in 2006, then continued to increase until 2016 and decreased in 2017, but it can be concluded that foreign debt from 2002 to 2017 generally increased. Reducing the number of poor people in Indonesia, desperately needs investment as a source of economic development, modernization, income growth, employment. Investment is an important component in national income and economic growth. Investment plays an important role in economic growth, it is important to determine investment strategies that will balance economic growth and sustainable development. Investment is a commitment of funds, directly or indirectly, to one or more assets in the hope of increasing future wealth. 
Figure 4: Investing in Indonesia since $2002-2017$

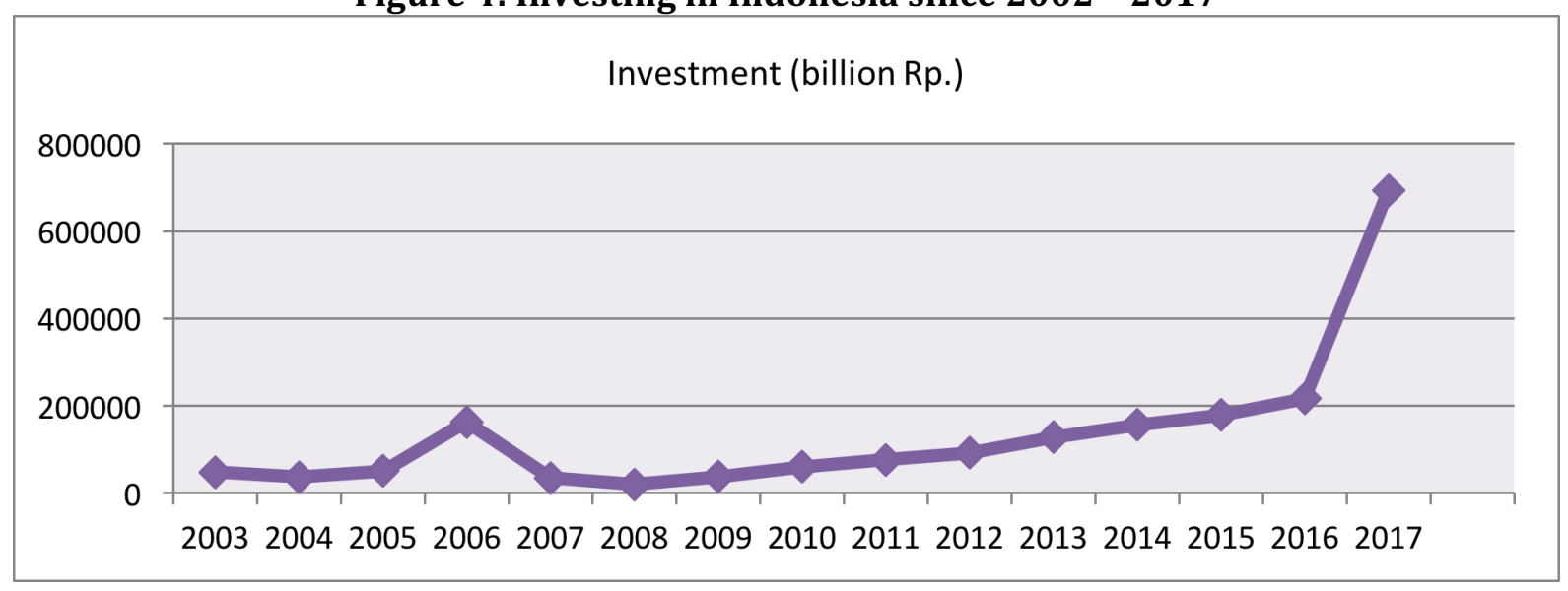

The data on the development of Indonesian investment from 2002 to 2017 shows that it increased in 2003, decreased in 2004, increased until 2006, declined again until 2008, then in 2009 it increased to in 2017, it can be established in general the development of Indonesian investment from 2002 to 2017 experienced a positive increase in the results of the development of regression analysis and the relationship between variables of tax revenue, foreign debt, development of investment and the poverty levels in Indonesia from $2002-2017$. The multiple regression equation $Y=42313600,962+0.840$ (tax revenue) $-53,563$ (foreign debt) $+0,794$ (Investing) shows that the amount of tax revenue and investment development has a positive effect on the amount of poverty which means that each increase in 1 score increases also the number of poverty of 0.840 and 53,563 in constant 42313600,96, medium foreign debt have a negative effect on the amount of poverty, meaning that each increase in 1 score of foreign debt decreases the amount of poverty by 0.794 in the constant 42313600.96 . While the results of the analysis of multiple correlation coefficients ( $r$ ) of 0.947 means that there is a relationship together is very strong among the four variables studied and the coefficient of determination $(\mathrm{R} 2)=0.896$. Which means that $89.6 \%$ of the number of poor people can be influenced by variable tax revenues, foreign debt and the development of investment together, the remaining $10.4 \%$ is influenced by other factors.

\section{CONCLUSION}

The results of the regression analysis and the relationship between the variables of tax revenue, foreign debt, development of investment and the poverty level from 2002 - 2017, indicate that tax revenues and investment levels have a positive effect or can be said to be unable to reduce poverty level, variable foreign debt have a negative effect or can be said to reduce poverty. While the results of the analysis of multiple correlation coefficients ( $r$ ) in the can of 0.947 means that there is a very strong together between the four variables studied and the coefficient of determination $\left(\mathrm{R}^{2}\right)=0.896$. Which means that as much as $89.6 \%$ of the number of poor people can be influenced by variables of tax revenues, foreign debt and developments of investment, the remaining $10.4 \%$ is influenced by other factors. Tax revenue and developments of investment have not been able to reduce poverty level, because with a high tax rate can affect the price level to increase by itself demand decreases as a result companies also reduce production and investment activities affect the decline in employment opportunities that can give birth to unemployment and poverty, one of them some are corrupted by certain people. Foreign debt can reduce poverty level, because the greater foreign debt are development activities that can absorb labor, thus affecting the decline in unemployment and the Indonesian poverty level. From the results of the study there needs to be an effort to suppress foreign labor and imports, improve the quality of human resources, both quality and character quality and preserved natural resources, control both individual 
communities, companies and governments, in order to be able to develop an increasingly better economy forwards.

\section{References}

Barrett, CB, \& Carter, MR (2013). The economics of poverty traps and persistent poverty: empirical and policy implications. The Journal of Studies Development, 49 (7), 976-990.

Barrett, CB, \& Swallow, BM (2006). Fractal poverty traps. World development, 34 (1), 1-15.

Hausmann, R., Pritchett, L., \& Rodrik, D. (2005). Growth accelerations. Journal of economic growth, 10 (4), 303329.

Indonesian Central Agency on Statistics. (2018). Jakarta

Malisa, M., \& Fakhruddin, F. (2017). Analysis of direct investment in Indonesia. Development Economics Student Scientific Journal, 2 (1), 116-124.

Molle, AI, Pangemanan, SS, \& Sabijono, H. (2014). Analysis of Factors Affecting Personal Taxpayers' Income Tax Receipts at Manado Primary Tax Office. EMBA Journal: Journal of Economic Research, Management, Business and Accounting, 2 (4).

Purwanto, NP, \& Mangeswuri, DR (2011). Effects of foreign investment and foreign debt on Indonesia's economic growth. Journal of Economics and Public Policy,2(2), 681-706.

Rusdarti, R., \& Sebayang, LK (2013). Factors That Affect Poverty Levels in Central Java Province. Economia Journal, 9 (1), 1-9.

The National Team for the Acceleration of Poverty Reduction (National Team for the Acceleration of Poverty Reduction or TNP2K). (2011). Poverty Reduction Current Situation, Government Targets, and Acceleration Program. Secretariat of the Vice President of the Republic of Indonesia. Jakarta

\section{APPENDIX 1: TAX REVENUE, FOREIGN DEBT, DEVELOPMENT OF INVESTMENT AND POVERTY LEVEL IN INDONESIA}

\begin{tabular}{ccccc}
\hline Years & $\begin{array}{c}\text { Poor Population } \\
\text { (householder in million Rp.) }\end{array}$ & Tax (billion Rp.) & $\begin{array}{c}\text { Foreign debt } \\
\text { (million USD) }\end{array}$ & Investment (billion Rp.) \\
\hline 2002 & $38,390,000$ & 219627 & 77818 & 25307.6 \\
2003 & $37,340,000$ & 364140 & 86650 & 48484.8 \\
2004 & $36,150,000$ & 272175 & 87036 & 37140.4 \\
2005 & $35,100,000$ & 297844 & 134504 & 50577.4 \\
2006 & $39,300,000$ & 416313 & 132633 & 162767.2 \\
2007 & $37,170,000$ & 509462 & 141180 & 34878.7 \\
2008 & $34,960,000$ & 658701 & 155080 & 20363.4 \\
2009 & $32,530,000$ & 619922 & 172871 & 37799.9 \\
2010 & $31,020,000$ & 742738 & 202413 & 60626.3 \\
2011 & $30,010,000$ & 850255 & 225375 & 76000.7 \\
2012 & $28,710,000$ & 1032570 & 252364 & 92182 \\
2013 & $28,600,000$ & 1192994 & 266109 & 128150.6 \\
2014 & $27,730,000$ & 1146866 & 293770 & 156126.3 \\
2015 & $28,510,000$ & 1379992 & 310730 & 179465.9 \\
2016 & $27,760,000$ & 1546665 & 316407 & 216238.1 \\
2017 & $26,580,000$ & 1498871 & 309067 & 692800 \\
\hline
\end{tabular}

